\title{
Mycobacterium parafortuitum: a New Species
}

\author{
By M. TSUKAMURA \\ The Obuso National Sanatorium, Obu near Nagoya, Aichi-Prefecture, Japan \\ (Received 13 May 1965) \\ SUMMARY \\ A new species Mycobacterium parafortuitum is described. A number of \\ strains of the genus Mycobacterium isolated from soil resembled $\boldsymbol{M}$. for- \\ tuitum in their rapid growth, in their pattern of utilization of organic acids \\ and in their pattern of amidase tests. However, these strains differed from \\ $M$. fortuitum in the following points: they showed negative 3-day aryl- \\ sulphatase test, they showed negative salicylate degradation and PAS \\ degradation, they did not utilize nitrite as sole nitrogen source, and they \\ formed acid from pentoses, arabinose, xylose, inositol and mannitol. This \\ group of strains has been named as $\boldsymbol{M}$. parafortuitum sp.nov.
}

\section{INTRODUCTION}

In the course of a study on 'atypical' mycobacteria isolated in Japan, the author isolated many acid-fast bacilli from the soil for comparison with the 'atypical' mycobacteria isolated from humans. Organisms isolated from soil, after treatment of soil samples with $4 \%(\mathrm{w} / \mathrm{v}) \mathrm{NaOH}$ and $4 \%(\mathrm{v} / \mathrm{v}) \mathrm{H}_{2} \mathrm{SO}_{4}$, were studied. Strains which were considered to be mycobacteria, on morphological grounds, were then classified according to their amidase pattern (Boenicke, 1962). Strains which showed the pattern characteristic for Mycobacterium fortuitum were then tested for 3-day arylsulphatase activity (Wayne, 1961), nitrite utilization (Tsukamura \& Tsukamura, 1965), and salicylate and $p$-aminosalycilate (PAS) degradation (Tsukamura, 1965). A group of strains showing positive reactions in three or four of these tests was classified as $M$. fortuitum. However, several strains which showed negative reactions in all of these tests were also found. These strains are considered to be a new species and their characters are considered in this paper.

\section{METHODS}

Growth rate and temperature response were observed on Löwenstein-Jensen medium.

Amidase tests were carried out according to the method of Boenicke (1962).

Three-day arylsulphatase test was carried out according to the method of Wayne (1961), and 3-week arylsulphatase test according to the method of Kubica \& Vestal (1961).

Utilization of organic acid as sole carbon source was observed in the following medium: $\left(\mathrm{NH}_{4}\right)_{2} \mathrm{SO}_{4}, 2.64$ g.; $\mathrm{KH}_{2} \mathrm{PO}_{4}, 0.5$ g.; $\mathrm{MgSO}_{4} .7 \mathrm{H}_{2} \mathrm{O}, 0.5$ g.; purified agar (Wako Chemical Co., Osaka), 30.0 g.; distilled water, $1000 \mathrm{ml}$. This was adjusted to pH $7 \cdot 0$ by addition of $10 \%(\mathrm{w} / \mathrm{v}) \mathbf{K O H}$ and the medium sterilized by autoclaving at $115^{\circ}$ for $30 \mathrm{~min}$. Organic acids (sodium salts) were sterilized at $100^{\circ}$ for $15 \mathrm{~min}$. and 
added to medium at a concentration of $0.01 \mathrm{M}$. The medium was readjusted to $\mathrm{pH}$ $\mathbf{7 \cdot 0}$ and sterilized at $100^{\circ}$ for $10 \mathrm{~min}$. Growth was observed after 2 weeks incubation at $37^{\circ}$.

Acid formation from sugars was tested in the following medium: $\mathrm{NH}_{4} \mathrm{Cl}, 2 \cdot 0 \mathrm{~g}$; $\mathrm{KH}_{2} \mathrm{PO}_{4}, 0.5$ g.; $\mathrm{MgSO}_{4} .7 \mathrm{H}_{2} \mathrm{O}, 0.5 \mathrm{~g} . ; 0 \cdot 2 \%(\mathrm{w} / \mathrm{v})$ bromothymol blue in $0.02 \mathrm{M}-\mathrm{NaOH}$, $20.0 \mathrm{ml}$.; purified agar, $30.0 \mathrm{~g}$.; distilled water, $1000 \mathrm{ml}$. (pH 7.2). Sugar solutions were sterilized separately by heating at $100^{\circ}$ for $5 \mathrm{~min}$. and added to medium aseptically to a final concentration of $0.5 \%(w / v)$. Acid formation was observed after 2 weeks incubation at $37^{\circ}$.

Utilization of nitrogen compounds as sole nitrogen source (including sodium nitrite) was tested on the following medium: glycerol, $50.0 \mathrm{ml}$; $\mathrm{KH}_{2} \mathrm{PO}_{4}, \mathbf{0 . 5} \mathrm{g}$.; $\mathrm{MgSO}_{4} .7 \mathrm{H}_{2} \mathrm{O}, 0.5 \mathrm{~g}$.; sodium citrate, $2 \cdot 0 \mathrm{~g}$.; purified agar, $30 \cdot 0 \mathrm{~g}$.; distilled water, $950 \mathrm{ml}$. ( $\mathrm{pH} 7 \cdot 0$ ). Nitrogen compounds were sterilized by heating at $100^{\circ}$ for $5 \mathrm{~min}$. or Seitz filtration (sodium nitrite) and added to medium aseptically to a final concentration of $0.02 \mathrm{M}$. Growth was observed after 2 weeks incubation at $37^{\circ}$.

Salicylate degradation was tested on Sauton agar medium containing $0.5 \mathrm{mg}$. and $1.0 \mathrm{mg}$. sodium salicylate $/ \mathrm{ml}$. Blackening of the medium after 7 days incubation at $37^{\circ}$ was recognized as positive degradation.

$P A S$ degradation was observed on Löwenstein-Jensen medium or Ogawa egg medium containing $1 \mathrm{mg}$. sodium $p$-aminosalicylate (PAS) $/ \mathrm{ml}$. Blackening of the medium after 7 days incubation at $37^{\circ}$ was recorded as a positive reaction.

Pathogenicity to mice (CF 1 strain) was tested by intravenous injection of the test strains in a dose of about $2 \mathrm{mg}$. (wet weight) per mouse. The viable numbers in the lungs and spleen were recorded as an index of pathogenicity. For the determination of the viable numbers in organs, three mice were killed every week and the lungs and spleens were homogenized (in a motor homogenizer) and mixed with 10 vol. saline containing 100 units $/ \mathrm{ml}$. penicillin G. The organ homogenates were diluted with saline to make $1 / 1-1 / 10^{4}$ dilutions: $0.02 \mathrm{ml}$. of each dilution was inoculated to Löwenstein-Jensen medium (five tubes for a dilution) and incubated at $37^{\circ}$. After 4 days incubation, the number of colonies was counted and viable numbers per organ calculated.

\section{RESULTS}

Characters of seven representative strains are shown in Table 1.

Morphology. Rods, 2-3 $\mu$ in length after cultivation for 3-4 days on LöwensteinJensen medium at $37^{\circ}$; acid-fast short bacillary to coccoid forms in old cultures. Non-motile. No cord formation in Dubos liquid medium without Tween. No mycelium was observed in slide culture even at early stage of incubation when acid-fast rods were present.

Löwenstein-Jensen medium. At 3-4 days growth was smooth, wet, thin, soft, creamy or pale yellow; at 10-14 days it became yellowish. A strain of group B (see below) was scotochromogenic. Strains 310 and 311 were mucoid.

Sauton agar medium. At 6-7 days growth was smooth, wet, soft, creamy or pale yellow. A strain of the group B was yellowish orange. In tables, non-photochromogenic strains were designated by ' $N$ ' and scotochromogenic (only one strain) by ' $\mathrm{s}$ '.

Temperature relations. Some strains showed good growth at $28-45^{\circ}$, but no growth at $52^{\circ}$. These strains were named group A. Other strains showed little or 
no growth at $45^{\circ}$ (Table 1). This group was named group B. Neither group A nor group B strains survived $60^{\circ}$ for $4 \mathrm{hr}$.

Salt tolerance. Growth variable in glycerol broth containing $5 \%(\mathrm{w} / \mathrm{v}) \mathrm{NaCl}$.

Nitrate reduction: variable.

Table 1. Physiological characteristics of Mycobacterium parafortuitum

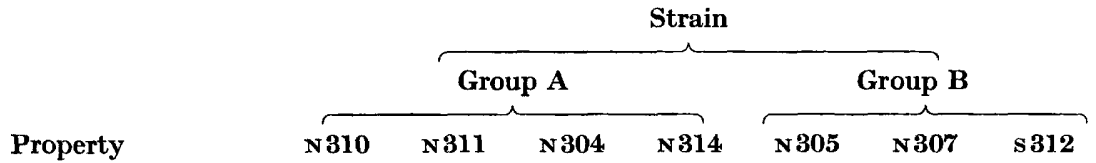

Growth at

$$
\begin{array}{r}
\mathbf{5 2}^{\circ} \\
\mathbf{4 5}^{\circ} \\
\mathbf{3 7}^{\circ}
\end{array}
$$

$28^{\circ}$

Acid from

Glucose

Mannose

Galactose

Arabinose

Xylose

Rhamnose

Trehalose

Lactose

Raffinose

Inositol

Mannitol

Sorbitol

Utilization of

Acetate

Citrate

Succinate

Malate

Pyruvate

Benzoate

Utilization of

Glycerol

Glucose

Fructose

Sucrose

Propyleneglycol

Amidase for

Acetamide

Benzamide

Urea

Isonicotinamide

Nicotinamide

Pyrazinamide

Salicylamide

Allantoin

Succinamide

Malonamide

$\mathrm{NaNO}_{3}$ reduction

3-day arylsulphatase test

3-week arylsulphatase test

$\begin{array}{lllllll}- & - & - & - & - & - & - \\ + & + & + & + & \pm & - & - \\ + & + & + & + & + & + & + \\ + & + & + & + & + & + & +\end{array}$

Salicylate degradation

PAS degradation

$\mathrm{NaNO}_{2}$ utilization 
Three-day arylsulphatase test: negative.

Three-weeek arylsulphatase test: positive.

Salicylate degradation: negative.

$P A S$ degradation: negative.

Amidase tests. Amidase positive for acetamide, urea, nicotinamide, pyrazinamide, and allantoin. Amidase negative for benzamide, isonicotinamide, salicylamide, succinamide, and malonamide. Incubation: $15 \mathrm{hr}$. Temperature: $37^{\circ}$.

Utilization of organic acids. Acetate, citrate, succinate and malate were utilized as sole carbon sources. Pyruvate was not utilized. No growth or scanty growth on medium containing benzoate as sole carbon source.

Acid formation from sugars. Acid was formed from glucose, mannose, arabinose, xylose, trehalose, inositol, and mannitol. No acid from galactose, lactose, raffinose, and sorbitol; rhamnose variable. Good growth or moderate growth on media containing most sugars, but scanty growth on media containing lactose or raffinose.

Table 2. Virulence to mice of strains of Mycobacterium parafortuitum

\begin{tabular}{|c|c|c|c|c|c|c|}
\hline \multirow[b]{2}{*}{ Strain } & \multirow[b]{2}{*}{ Inoculum } & \multirow[b]{2}{*}{ Organ } & \multicolumn{4}{|c|}{ Viable numbers per organ* } \\
\hline & & & 1 week & 2 weeks & 3 weeks & 4. weeks \\
\hline N310 & $1 \cdot 3 \times 10^{8}$ & $\begin{array}{l}\text { Lungs } \\
\text { Spleen }\end{array}$ & $\begin{array}{l}<18 \\
760\end{array}$ & $\underset{715}{<16}$ & $\begin{array}{l}<16 \\
<12\end{array}$ & . \\
\hline N311 & $2.0 \times 10^{8}$ & $\begin{array}{l}\text { Lungs } \\
\text { Spleen }\end{array}$ & $\begin{array}{l}<18 \\
6300\end{array}$ & $\begin{array}{r}\mathbf{2 2 9} \\
\mathbf{3 6 3 0}\end{array}$ & $\begin{array}{l}<16 \\
1350\end{array}$ & $\begin{array}{l}<18 \\
24\end{array}$ \\
\hline N 304 & $9 \cdot 7 \times 10^{8}$ & $\begin{array}{l}\text { Lungs } \\
\text { Spleen }\end{array}$ & $\begin{array}{l}<23 \\
440\end{array}$ & $\begin{array}{l}<\mathbf{2 0} \\
<\mathbf{3 0}\end{array}$ & $\begin{array}{l}<18 \\
<22\end{array}$ & . \\
\hline N314 & $1.0 \times 10^{9}$ & $\begin{array}{l}\text { Lungs } \\
\text { Spleen }\end{array}$ & $\begin{array}{l}<10 \\
<17\end{array}$ & $\begin{array}{l}<15 \\
124\end{array}$ & $\begin{array}{l}<17 \\
<25\end{array}$ & . \\
\hline N305 & $\mathbf{3 . 5} \times 10^{8}$ & $\begin{array}{l}\text { Lungs } \\
\text { Spleen }\end{array}$ & $\begin{array}{l}<15 \\
6320\end{array}$ & $\begin{array}{c}<\mathbf{2 6} \\
\mathbf{5 3 3 0}\end{array}$ & $\begin{array}{l}<27 \\
545\end{array}$ & $\begin{array}{l}<\mathbf{2 0} \\
<\mathbf{2 4}\end{array}$ \\
\hline
\end{tabular}

* Average in three mice. Inoculation was made intravenously. At different intervals, the mice inoculated were sacrificed and viable numbers of bacteria were counted by dilution plating technique.

Utilization of nitrogen compounds as sole nitrogen source. L-Glutamate, L-leucine, L-glycine, L-serine, L-methionine, ammonium sulphate, ammonium chloride, sodium nitrate, nicotinamide, and urea were utilized. Isonicotinamide and pyrazinamide variable. Sodium nitrite not utilized.

Pathogenicity to mice. Intravenous injection of the strains at a dose of $\mathbf{2} \mathbf{m g}$. wet weight did not kill mice within 1 month. No macroscopic lesions were observed in the mice and intravenously injected bacilli were eliminated rapidly from mouse organs. Among the strains tested, N 311 and N 305 were eliminated more slowly than the other strains (Table 2).

\section{DISCUSSION}

In view of the results, the most useful characteristics for recognizing the strains described in this paper are: (1) rapid growth on egg media; (2) good growth at $45^{\circ}$ for group $A$-this characteristic most easily differentiates this group from $M$. fortuitum; (3) negative 3-day arylsulphatase reaction; (4) inability to decompose salicylate or PAS; (5) failure to utilize sodium nitrite as sole nitrogen source within 1 week; (6) amidase positive for acetamide, urea, nicotinamide, pyrazinamide, and 
allantoin; amidase negative for benzamide, isonicotinamide, salicylamide, succinamide, and malonamide after incubation at $37^{\circ}$ for $15 \mathrm{hr}$; (7) ability to form acid from glucose, mannose, arabinose, xylose, trehalose, inositol, and mannitol; inability to form acid from galactose, raffinose, and sorbitol; (8) failure to utilize

Table 3. Comparison of physiological characteristics of Mycobacterium fortuitum, M. parafortuitum, M. smegmatis, and M. rhodochrous

\begin{tabular}{|c|c|c|c|c|}
\hline Property & M. fortuitum* & $\begin{array}{l}\text { M. para- } \\
\text { fortuitum }\end{array}$ & $\underset{\text { matis* }^{\text {M. smeg- }}}{\text { - }}$ & $\begin{array}{c}\text { M. rhodo- } \\
\text { chrous* }\end{array}$ \\
\hline \multicolumn{5}{|l|}{ Growth at } \\
\hline at $52^{\circ}$ & - & - & - & - \\
\hline at $45^{\circ}$ & - & Variable & + & Variable \\
\hline at $37^{\circ}$ & + & + & + & + \\
\hline \multicolumn{5}{|l|}{ Acid from } \\
\hline Glucose & + & + & + & + \\
\hline Mannose & + & + & + & + \\
\hline Galactose & Rare & - & + & Rare \\
\hline Arabinose & Rare & + & + & - \\
\hline Xylose & Rare & + & + & Rare \\
\hline Rhamnose & - & Variable & + & Rare \\
\hline Trehalose & + & + & + & + \\
\hline Lactose & - & - & - & - \\
\hline Raffinose & - & - & - & - \\
\hline Inositol & Rare & + & + & Rare \\
\hline Mannitol & Variable & + & + & + \\
\hline Sorbitol & Rare & - & + & + \\
\hline Utilization of benzoate & - & - & + & + \\
\hline 3-day arylsulphatase test & + & - & - & - \\
\hline Salicylate degradation & + & - & - & . \\
\hline PAS degradation & + & - & - & . \\
\hline $\mathrm{NaNO}_{2}$ utilization & + & - & $(+)$ & . \\
\hline
\end{tabular}

Table 4. Comparison of physiological characteristics among Mycobacterium fortuitum, $M$. parafortuitum, and $M$. smegmatis

\begin{tabular}{|c|c|c|c|}
\hline Property & M. fortuitum* & M. parafortuitum & M. smegmatis* \\
\hline \multicolumn{4}{|l|}{ Amidase for } \\
\hline Acetamide & + & + & -ort \\
\hline Benzamide & - & - & + \\
\hline Urea & + & + & + \\
\hline Isonicotinamide & - & - & + \\
\hline Nicotinamide & tor- & + & + \\
\hline Pyrazinamide & tor- & + & + \\
\hline Salicylamide & - & - & -ort \\
\hline Allantoin & tor- & + & - \\
\hline Succinamide & - & - & + \\
\hline Malonamide & - & - & - \\
\hline
\end{tabular}

benzoate; (9) colonies slightly pigmented or non-pigmented; (10) rapid elimination from mouse body

By comparison of these data with the descriptions of Gordon \& Mihm (1959), Gordon \& Smith (1955), and Boenicke (1962), the strains described in this paper are differentiated from Mycobacterium fortuitum, M. smegmatis, M. rhodochrous and $M$. phlei Tables 3, 4). 
The most important reactions separating these strains from those of Mycobacterium fortuitum are: negative 3-day arylsulphatase test; negative salicylate and PAS degradation tests; failure to utilize nitrite as sole nitrogen source; acid production from arabinose, xylose, and inositol; growth at $45^{\circ}$ (group A).

The most important reactions separating the strains from Mycobacterium smegmatis are: failure to form acid from galactose or sorbitol; failure to utilize benzoate as sole carbon source; negative reactions for benzamidase, isonicotinamidase, and succinamidase; positive reaction for allantoinase.

The most important reactions separating the strains from those of Mycobacterium rhodochrous are: acid production from arabinose, xylose and inositol; inability to form acid from sorbitol; inability to utilize benzoate as sole carbon source.

The most important reactions separating the strains from Mycobacterium phlei are: no growth at $52^{\circ}$; failure to survive $4 \mathrm{hr}$ at $60^{\circ}$; acid production from inositol; inability to form acid from sorbitol; positive reaction for allantoinase.

By these comparisons, the strains described in this study were differentiated from the known species and considered to belong to a new species. The author proposes to name this group of strains Mycobacterium parafortuitum sp.nov.

Strains 310 and 311 have been deposited in the National Collection of Type Cultures, Colindale Avenue, London, N.W.9.

Strain 310 is NCTC 10410.

Strain 311 is NCTC 10411.

\section{REFERENCES}

BoENICKE, R. (1962). L'identification des mycobactéries à l'aide des méthods biochimiques. Bull. Un. int. Tuberc. 32, 13.

Gordon, R. E. \& Mrhm, J. M. (1959). A comparison of four species of mycobacteria. J. gen. Microbiol. 21, 736.

Gondon, R. E. \& Smith, M. M. (1955). Rapidly growing, acid fast bacteria. II. Species description of Mycobacterium fortuitum Cruz. J. Bact. 69, 502.

Kubica, G. P. \& Vestal, A. L. (1961). The arylsulfatase activity of stock cultures of acidfast bacilli. Am. Rev. resp. Dis. 83, 728.

Tsukamura, M. (1965). Salicylate degradation test for differentiation of Mycobacterium fortuitum from other mycobacteria. J. gen. Microbiol. 41, 309.

Tsukamura, M. \& Tsukamura, J. (1965). Differentiation of mycobacteria by utilization of nitrite as sole nitrogen source. J. Bact. 89, 1442.

WAYNE, L. G. (1961). Recognition of Mycobacterium fortuitum by means of a three-day phenolphthalein sulfatase test. Am. J. clin. Path. 36, 185. 